\title{
Recent Cases on the Calculation of ROYALTIES ON First Nations' LANDS
}

\author{
Nigel Bankes" and L. Douglas RaE**
}

This article examines the statutory and regulatory framework for the calculation of royalties for oil and gas produced from First Nations' lands. Against this backdrop, the article goes on to explore in detail three recent cases involving different aspects of royalty calculation for on-reserve resources and attempts to synthesize these divergent decisions.

\begin{abstract}
Les auteurs examinent d'abord les lois et le cadre de réglementation régissant le calcul des redevances pétrolières et gazières appartenant aux autochtones; ils procèdent ensuite $\dot{a}$ un examen approfondi de trois arrêts récents portant sur les ressources dans les réserves et tentent de mettre en rapport ces décisions divergentes.
\end{abstract}

\section{TABLE OF CONTENTS}

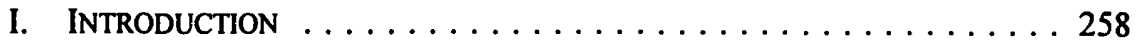

II. THE OIL AND GAS REgIME FOR INDIAN LANDS $\ldots \ldots \ldots \ldots \ldots 261$

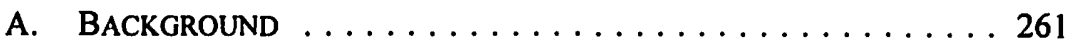

B. THE Royalty ProvisIons $\ldots \ldots \ldots \ldots \ldots \ldots \ldots 262$

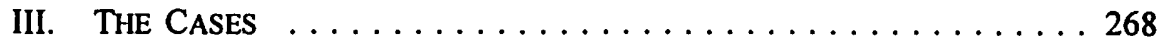

A. IMPERIAL OIL RESOURCES V. CANADA (MINISTER

OF INDIAN AFFAIRS AND NORTHERN DEVELOPMENT) . . . . 268

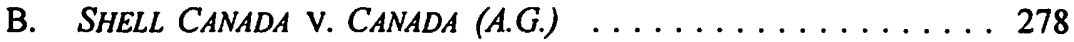

C. Stoney TRIBAL CounCIL v. PANCANADIAN PETROLEUM .... 281

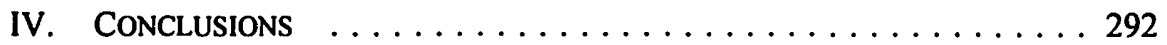

\section{INTRODUCTION}

The past year has seen three decisions on the valuation and calculation of royalties on production of oil and natural gas from First Nations' lands. While the decisions are firmly rooted in "conventional" oil and gas law and principles of administrative law, the regime governing these lands is unique. The statutory regime is specific to Indian lands, and the interpretation of the regime should reflect the unique constitutional position of Indian lands and the fiduciary relationship between the Crown and aboriginal peoples.

Two of the decisions originated in the Federal Court, Imperial Oil Resources v. Canada (Minister of Indian Affairs and Northern Development' and Shell Canada v. Canada (A.G.), ${ }^{2}$ while the third is a decision of McIntyre J. of the Alberta Court of Queen's Bench, Stoney Tribal Council v. PanCanadian Petroleum. ${ }^{3}$ In addition to this

\footnotetext{
Professor of Law, Faculty of Law, University of Calgary. Nigel Bankes' contribution to this article is based in large part on a paper that he prepared for presentation to the CBA mid-winter meeting, Edmonton, January, 1999.

-. Barrister and Solicitor, Rae and Company, Calgary.

$1 \quad$ [1997] F.C.J. No. 1767 (T.D.), online: QL (FCJ) [hereinafter Imperial].

2 [1998] F.C.J. No. 1525 (C.A.), online: QL (FCJ) aff' [1998] 3 F.C. 223 (T.D.) [hereinafter Shell].

3 [1999] 1 C.N.L.R. 219, 218 A.R. 210 (Q.B.) [hereinafter Stoney].
} 
group of three cases, there are at least three other important Indian royalty cases that are at various stages of interlocutory proceedings. Two of the cases are brought by the Samson and Ermineskin Indian bands and involve breach of trust allegations against the federal Crown. ${ }^{4}$ Those actions are proceeding in the Federal Court. The plaintiffs argue, inter alia, that Indian royalties should have been calculated on the basis of world prices and not regulated prices during the period from 1974 to 1985 . A third case, involving the same pool, is an action commenced by Chevron Canada Resources ("Chevron") 5 seeking recovery for royalty overpayments that it claims were made by mistake. The Indian bands involved have filed a counterclaim alleging that the underlying leases are invalid and seeking damages far in excess of the original claim made by Chevron. ${ }^{6}$

These cases should be considered within a broader context that has seen an explosion of Aboriginal and First Nations litigation over the last couple of decades. But, with few exceptions, most of this litigation has involved hunting and fishing rights, treaty entitlement claims, and the Crown's fiduciary obligations to aboriginal peoples. The Lubicon case in Alberta in the early 1980s served as an early indicator of how that litigation might affect the oil and gas industry and the Crown's claims to beneficial title. ${ }^{7}$ The Blueberry River Indian Band v. Canada (Department of Indian Affairs and Northern Development ${ }^{8}$ decision of the Supreme Court of Canada gave the Crown an unpleasant reminder of the large financial liability that might result from ignoring its

$4 \quad$ The list of preliminary rulings includes: Ermineskin Indian Band v. Canada (Minister of Indian Affairs and Northern Development), [1997] F.C.J. 1111 (T.D.), online: QL (FCJ), Samson Indian Nation and Band v. Canada (Minister of Indian Affairs and Northern Development), [1995] 2 F.C. 762 [hereinafer Samson] (the trust principle for the disclosure of documents to the beneficiary of a trust could not apply to Crown trusts without amendment), Samson Indian Nation and Band $\mathbf{v}$. Canada (Minister of Indian Affairs and Northern Development), [1998] 2 C.N.L.R. 199 (F.C.A.), aff $g$ [1997] 1 C.N.L.R. 180 (F.C.T.D.) (issues of privilege in the production of documents, First Nation entitled to access to any legal advice relating to the surrender of oil and gas and mineral resources and royalties).

For some of the preliminary proceedings see Chevron Canada Resources v. Canada (Executive Director of Indian Oil and Gas Canada) (1997), 53 Alta. L.R. (3d) 153 (Q.B.) (application by Chevron to pay future royalties into court or into a trust dismissed). In Chevron Canada Resources v. Canada (Executive Director of Indian Oil and Gas Canada), [1999] A.J. No. 421, online: QL (AJ) [hereinafter Chevron], Ermineskin applied to enjoin Crown counsel from acting and to allow Ermineskin to appoint and instruct counsel to defend the action on behalf of the Crown and at Crown expense. The application was dismissed. Moore C.J. found the Crown to be in an actual or potential conflict of interest because of third party action alleging that, if the Crown were found to owe monies to Chevron, the Crown should be able to recover those monies from the band. The conflict, however, was a conflict of the Crown and not of Crown counsel and would not be alleviated by the appointment of other Crown counsel. Chevron Canada Resources v. Canada (Executive Director of Indian Oil and Gas Canada), [1998] A.J. No. 1202 (Q.B.), online: QL (AJ) (application by the federal Crown to strike out the Indian counterclaim as against the Crown was dismissed).

7 Ominayak v. Norcen Energy Resources, [1985] 3 W.W.R. 193 (Alta. C.A.).

8 [1995] 4 S.C.R. 344, 130 D.L.R. (4th) 193 [hereinafter Apsassin]. The action was remitted to the Trial Division of the Federal Court for assessment of damages. The parties reached a settlement incorporated in a consent order for $\$ 147,000,000$. There is ongoing litigation to determine eligibility to participate in the award: Blueberry River Indian Band v. Canada (Department of Indian Affairs and Northern Development), [1999] F.C.J. No. 452 (T.D.), online: QL (FCJ). 
fiduciary obligations with respect to the oil and gas rights accruing to reserves, ${ }^{9}$ while the dramatic 1997 decision in Delgamuukw v. British Columbia (A.G.) $)^{10}$ suggests that claims of aboriginal title include oil and gas rights and casts further doubt on the application of provincial resource disposition laws in areas of a province subject to a title claim. More recent decisions, especially in the Treaty 8 area of British Columbia (and to a lesser extent in Alberta "), consider the extent to which the Crown has met its fiduciary and constitutional obligations prior to disposing of Crown resources or issuing regulatory approvals.

The three cases that are considered in this article deal with a narrower range of issues. All three decisions examine the permissibility of deductions claimed by lessees of oil and gas rights underlying Indian lands. All three decisions deal with the pricing and valuation of gas and gas products, ${ }^{12}$ but the principles enunciated also have important ramifications for the valuation of oil for royalty purposes. One of the cases, the Stoney case, also raises larger questions as to the application of provincial laws to lands reserved. More broadly, the cases also raise some interesting questions as to the choice of forum and the interplay between public and private law. The Stoney case was commenced by way of statement of claim in provincial superior court, whereas the Imperial and Shell cases came before the courts on an application for judicial review.

The first part of this article lays out the basic framework for the disposition of oil and gas rights on Indian lands and the collection of royalties from production on Indian

See also Bruno v. Canada (Minister of Indian Affairs and Northern Development), [1991] 2 C.N.L.R. 22 (F.C.T.D.).

(1997), 153 D.L.R. (4th) 193 (S.C.C.).

1 See Athabasca Tribal Council v. Alberta (Minister of Environmental Protection), [1998] A.J. No. 1154 (Q.B.), online: QL (AJ) and [1998] A.J. No. 1157 (Q.B.), online: QL (AJ). This action was commenced as an application for judicial review of a decision by an official within the Department of the Environment to issue a geophysical exploration approval to Rio Alto Exploration Ltd. under the terms of the Mines and Minerals Act, R.S.A. 1980, c. M-15, and the regulations. The first judgment referred to represents Medhurst J.'s reasons for decision on a successful application from the province to convert the application from a judicial review application to a trial. Three days later Dixon $\mathrm{J}$. handed down reasons for judgment in the same matter granting an intervention application from the Canadian Association of Petroleum Producers. In British Columbia, see Blueberry River Indian Band v. British Columbia (Ministry of Employment and Immigration), [1997] B.C.J. No. 2864 (S.C.), online: QL (BCJ), Kelly Lake Cree Nation v. British Columbia (Minister of Energy and Mines), [1998] B.C.J. No. 2471 (S.C.), online: QL (BCJ). In addition, in Yukon, see Vuntut Gwitchin Tribal Council v. Canada (Minister of Indian Affairs and Northern Development), [1997] F.C.J. No. 1459 (T.D.), online: QL (FCJ), aff d[1998] F.C.J. No. 755 (C.A.), online: QL (FCJ), (environmental assessment issue in relation to re-entry of a well in the Eagle Plains area).

Note however that in the Imperial case the range of issues was originally much broader than those brought forward on the judicial review application and included questions related to the selling price of oil and the oil pipeline tariff between the Bonnic Glen field and Edmonton. For details see G.J. DeSorcy, Report to Minister of Indian Affairs and Northern Development, Re: Imperial Oil Resources Limited - Bonnie Glen Oil Field - Pigeon Lake Indian Reserve No. 138A, 10 July 1996 [hereinafter "DeSorcy Report"]. The DeSorcy Report was appended to the decision of the minister, 25 November 1996. The minister's decision is an exhibit to the affidavit of Douglas Baldwin filed in support of Imperial Oil Ltd.'s originating notice of motion in Imperial. 
lands. The second part of this article focuses on the three decisions and the final part of this article offers some conclusions.

\section{The OIL AND GaS Regime fOR INDIAN LANDS}

\section{A. BACKgRound}

Although there are exceptions, it is well accepted that the oil and gas rights underlying Indian reserves within the provinces accrue to the respective First Nations. ${ }^{13}$ Where that is the case, the federal government has developed a separate and unique federal regime to handle the disposition of these oil and gas rights and the collection of rents therefrom. This regime is presently embodied in the Indian Oil and Gas Act $^{14}$ and the Indian Oil and Gas Regulations, 1995. ${ }^{15}$

The Indian oil and gas regime is not new. Regulations under the Indian $A c t^{16}$ dealing with the disposition of mineral rights were first passed as early as $1927 .{ }^{17}$ Like the Alberta mineral disposition scheme, these regulations evolved from the pre-1930 period when all public lands in western Canada were under federal jurisdiction. They were also a direct product of the development of the conventional oil and gas industry in the United States. However, the particular terms of the Indian oil and gas regime have always come directly from specific regulations passed pursuant to a federal statute, previously the Indian $A c t^{18}$ and presently the Indian Oil and Gas Act. ${ }^{19}$ The current Act dates from 1974 while the original 1977 regulations were amended in 1995. The current regulations are known as the Indian Oil and Gas Regulations, 1995.

The basic elements of the tenure scheme under the current regulations involve an exploration tenure in the form of a permit and a production tenure in the form of a lease. All dispositions of reserve land require the surrender or designation of reserve lands under the Indian Act and the approval of the First Nation under the terms of the Indian Oil and Gas Regulations, 1995. Section 4 of the Indian Oil and Gas Act stipulates that all oil and gas obtained from Indian lands is subject to the payment of royalties as prescribed from time to time by the regulations. The same section goes on to provide that with the approval of the council of the band concerned, the minister may enter into a special agreement with any person for the reduction, increase, or variation in the prescribed royalties. While such "special agreements" are increasingly common, all three cases considered here involve royalties governed by the regulations.

The most authoritative treatment of the subject is R. Bartlett, Indian Reserves and Aboriginal Lands in Canada (Saskatoon: University of Saskatchewan Native Law Centre, 1990) and R. Bartlett, Resource Development and Aboriginal Land Rights (Calgary: Canadian Institute of Resource Law, 1991).

14 R.S.C. 1985 , c. 1-7.

is SOR/94-753.

16 R.S.C. 1906 , c. 81.

17 Order in Council dated 7th day of February, 1927, P.C. 1927-183.

18 Supra note 16.

19 Supra note 14. 


\section{B. The Royalty Provisions}

In reviewing the royalty provisions of the regulations, it is important to keep in mind two different issues. The first is the problem of allowable deductions for processing and transportation. The second and quite distinct problem is the problem of valuation of the product for royalty purposes. Initially the 1977 regulations are discussed, and then the 1995 regulations are considered.

The question of what deductions the payor of a gross royalty may legitimately take is ultimately a question of construction. There is no proposition of law that states that a payor will always be able to deduct a proportionate share of costs incurred from the wellhead to the point of sale. In the case of First Nations lands, it must also be borne in mind that being dealt with here is a unique statutory scheme that may or may not resemble a freehold leasing regime. Consequently, one must beware of importing settled understandings as to the interpretation of the freehold lease and applying those understandings to the statutory relationship between the federal Crown and the Indian oil and gas lessee. For example, it may be well understood in the freehold lease context that royalty is payable on market value at the wellhead and that the lessee is allowed to netback its transportation and processing costs from the point of sale to the point of production. There is no obvious reason for importing that understanding into the interpretation of the lessee's obligations under the Indian oil and gas regime unless that interpretation is required by the words used in the statute. The language of the Indian Oil and Gas Act makes it crystal clear that it is the language of the statute and regulations that is important and not the language of the lease. Furthermore, there is a significant body of case law which establishes that, in interpreting statutes related to Indians, "doubtful expressions" should be resolved in favour of the Indians. ${ }^{20}$

\section{Allowable Deductions}

The 1977 Indian Oil and Gas Regulations ${ }^{21}$ stated that the royalty payable shall be the royalty computed in accordance with the schedule ${ }^{22}$ and that every sale of oil or gas from Indian lands by an operator shall include the royalty share unless otherwise directed (s. 21(3)). The schedule provided for a basic royalty calculated as a fixed share of production ( 25 percent for gas and between 10 percent and 26 percent for oil on a sliding scale determined by reference to the amount of production) plus a supplementary royalty, calculated as an escalating share of sales prices of the lessee's share of production above stipulated base prices (essentially the price of oil, gas, and

This is not the occasion to provide a full assessment of these cases but the key authorities are: Nowegijick v. R., [1983] I S.C.R. 29, Mitchell v. Peguis Indian Band, [1990] 2 S.C.R. 85 [hereinafter Mitchell], and Opeichesaht Indian Band v. Canada (A.G.), [1998] 1 C.N.L.R. 134 (S.C.C.) especially at 156, (McLachlin J. dissenting).

21 SOR77-330, C.R.C. 1978, c. 963 . However, this royalty regime is not mandatory and current leasing practice is to utilize "special agreements" that do not use the statutory royalty set out in the regulations. 
products on 1 April 1974). ${ }^{23}$ Section 1 of Schedule I dealt with oil royalties and s. 2, with gas royalties.

Neither provision of the schedule stated that royalty was payable on the market value of the products at the wellhead, but both provisions stipulated that all quantities or amounts should be calculated at the time and place of production, free and clear of any deduction whatsoever. In the case of natural gas, s. 2(2) contained the additional qualifier "except as provided in s. (4)." That subsection provided as follows:

(4) Where gas is processed by a method other than gravity, the royalty of the gas obtained therefrom shall be calculated on the actual selling price of that gas, but such costs of processing as the Manager may from time to time consider fair and reasonable ... shall be allowed. ${ }^{24}$

One obvious possible interpretation of the regulations is simply that the only deductions that are permitted are such fair and reasonable processing costs with respect to gas as the manager may permit. No other deductions, whether for marketing or transportation or administration, are deductible. Production at the wellhead is the point for determining volumes and the timing of production, but it is not important for determining value.

The problem with this interpretive approach is that it ignores the well-established practice in the industry for dealing with the situation in which the lessee sells production downstream of the wellhead. In the case of gas, the first point of sale is typically at the outlet valve of the processing plant, but it may be into a far distant market. In the case of oil, the first point of sale may be at the field or at a later transshipment point. If there is no arm's length purchase and sale at the wellhead and if the royalty is payable on "market value at the wellhead" or some such similar formula, a common method of establishing the value of the hydrocarbons for royalty purposes has been to "netback" from the first point of sale. In Acanthus Resources v. Cunningham, a case dealing with freehold royalties, Hart J. stated:

It has long been recognized both in the oil and gas industry as well as law, however, that a value can be established at various points upstream of the market or point of sale by deducting costs incurred downstream of any such point to the actual point of sale. ${ }^{25}$

But it is important to emphasize that the netback methodology is only justified where a royalty is payable at market value at the wellhead and there is no such market. If there is a market at the wellhead, there is no issue, but if the lessee commits to pay a royalty at the outlet valve of the processing plant, or at the first point of sale, wherever that may be, there is no necessary entitlement to netback to the point of production especially if, as here, the royalty clause prohibits all deductions other than specified deductions.

There is some argument that the legal characteristics of the supplementary royalty may differ from those of the basic royalty.

Supra note 21 .

25

[1998] A.J. No. 25, online: QL (AJ), 213 A.R. 375 (Q.B.) at para. 11 [hereinafter Acanthus]. 
But the idea that lessees should be able to claim for a proportionate share of costs from the point of production to the point of sale is well entrenched in Canadian oil and gas law. ${ }^{26}$ It is perhaps for this reason that Indian Oil and Gas Canada ${ }^{27}$ permits the deduction of transportation costs in order to calculate a value at the wellhead, the place of production, for royalty purposes. ${ }^{28}$

The new 1995 regulations ${ }^{29}$ attempt to clarify the matter, although arguably they add to the confusion by adopting different language for each of the oil and gas royalty. First, with respect to oil, the schedule now provides that the royalty (and not just quantities or amounts of production) shall be "calculated at the time and place of production." The supplementary royalty continues to be based upon the "actual selling price" or, more accurately, the price at which the oil is sold. ${ }^{30}$ The 1995 regulations no longer contain the stipulation "free and clear of any deduction whatsoever" with respect to oil royalties.

Secondly, with respect to gas, s. 2 of Schedule I to the 1995 regulations stipulates that the royalty that is payable is "the gross royalty value of the gas." The gross royalty value of the gas is defined (s. 2(2)) as the basic gross royalty of 25 percent based upon the actual selling price, plus a supplementary royalty also determined by reference to the actual selling price of the gas, all calculated "at the time and place of production." Subsection 2(1) goes on to state explicitly that the royalty payable is reduced by "the portion of the cost of gathering, dehydrating, compressing and processing the gas that is equal to its gross royalty value divided by its total value." Further, the regulations explicitly state that price is defined as the price specified in the gas sales contract under

See for example Resman Holdings v. Huntex, [1984] I W.W.R. 693 (Alta. Q.B.) [hereinafter Huntex], a case in which the court effectively allowed custom and practice in the industry to override the explicit language of the agreement. Indian Oil and Gas Canada and its executive director have administrative authority over the Indian Oil and Gas Regulations.

See DeSorcy Report, supra note 12 at 13: "All parties, including the Reviewer, agree that the intent of the Legislation, Regulations and Agreements is that royalties calculated 'at the time and place of production' should include the cost of transporting the oil from Bonnie Glen to Edmonton." The First Nations themselves have frequently taken the position that the only permissible deductions are the allowed processing deductions for gas. Supra note 15.

30 Note that the term "actual selling price" is not used in relation to the basic royalty for oil. The basic royalty is expressed entirely as a percentage of production on the sliding scale. Note as well that, unlike the gas provisions, the oil provisions do not provide a list of the categories of costs that the lessee is entitled to share with the lessor. Thus there will still be some room for argument. For example, while Acanthus, supra note 25, may well be authority for the proposition that a freehold lessee can require its lessor to share water treatment costs as well as transportation costs, there may be some argument to the effect that these costs are properly "costs of production" (just like drilling the well) and are necessary to make the product marketable and therefore should be borne 100 percent by the lessee. In any event, it is not clear from Acanthus precisely which treatment costs are included. Is it just costs associated with the separation facility or do these costs extend to costs associated with the re-injection well, and where do we draw the line? Thanks to Owen Anderson for suggesting this line of questions based upon his understanding of the American case law. 
which the gas is sold "free and clear of any fees or deductions other than transmission charges beyond the facility gate."

Thus, if the gas is sold ex the processing plant, the lessee is clearly entitled to deduct its costs to that point on the basis of the express authorization of s. 2(1) of the schedule to the 1995 regulations (cost of gathering, dehydrating, etc.). If the gas is sold in, say, Toronto, the lessee can deduct its transportation costs from "the facility outlet" to the point of delivery in Toronto on the basis of the definition of price in s. 4 of Schedule I, and can deduct for charges upstream from the facility outlet on the basis of s. 2(1) of the schedule. No other costs incurred by the lessee are deductible.

The 1995 regulations continue to impose on the lessee the obligation to sell the lessor's royalty share unless otherwise instructed.

\section{Valuation or Market Price}

As noted above, the royalty is payable either explicitly or implicitly on the actual selling price of the product. The term "actual selling price" is defined as the greater of (1) "the price at which oil (or gas) is sold," and (2) "fair value" (1995 regulations) or "the dollar value of the oil or gas that would be realized if it were sold in a business-like manner, at the time and place of production in an arm's length transaction" (1977 regulations).

In the normal course of business, the "price at which oil or gas is sold" (usually) and "fair value" (always) will arise through the interplay of market forces which are independent of the royalty payor's control. Put another way, they constitute values resulting from business-like sales at arm's length, as the 1977 regulations correctly reflect. The corollary is that the "fair value" of oil or gas can only be determined when there are sales of such oil or gas, or other identical commodities, at arm's length. Fortunately, oil and gas and their products are directly substitutable commodities and these determinations of price or value can almost always be made.

As we have seen, producers often sell the produced oil and gas at the wellhead or downstream at the processing plant. Sometimes they sell to the ultimate consumers many thousands of kilometres away. Integrated producers, on the other hand, oftentimes themselves consume and refine their produced oil and gas into new products. Sometimes the ultimate sale of the oil and gas may not be at arm's length. Both the 1977 and the 1995 regulations were drafted in contemplation of all these eventualities. If the oil or gas is never sold in an arm's length transaction, but rather is consumed or transformed into another commodity, then the starting point would be the value of directly substitutable commodities.

Both the 1977 and 1995 regulations define the term "actual selling price," and both sets of regulations provide the administrator with the authority to determine a fair market value in the event that the administrator believes that the lessee is not selling at fair value. 
Under the 1977 regulations, the term "actual selling price" was simply defined as "the price at which the gas is sold" or the price determined by the administrator, "whichever is greater." The provision in the 1995 regulations is more detailed primarily, it would seem, to capture the idea that product (and specifically gas) may be sold into a distant market downstream of the processing plant but also specifically to allow the lessee to charge transportation costs (but no other costs) downstream of the plant.

For the purposes of sections 1 and 2, "actual selling price" means the greater of

(a) in respect of

(i) oil, the price at which the oil is sold, and

(ii) gas, the price or other consideration payable that is specified in the gas sales contract under which the gas is sold, free of any fees or deductions other than transmission charges beyond the facility outlet; and

(b) the fair market value of the oil or gas, determined pursuant to subsection 33(6) of these Regulations."

Rothstein J. spoke to this amendment in Imperial when he observed that:

By this amendment, it would appear that the Regulations now contemplate the "downstream" selling price (although this is not explicitly stated) and require that the plant gate price reflect only transmission charges "beyond the facility outlet" but no other charges. ${ }^{32}$

As has already been seen, the clear implication of this amendment and Rothstein's J.'s comments is that other downstream charges (i.e. ex the processing plant) such as marketing fees are simply not deductible under the 1995 regulations.

Faced with a situation in which there is reason to believe that there may be a manipulated price, both the 1977 and 1995 regulations confer on the manager or the executive director the power to deem a price.

The relevant section in the 1977 regulations is $s .21(7)$ :

21(7) Where oil or gas that is the royalty payable under these Regulations ... is sold or to be sold and, in the opinion of the Manager, the sale was or will be at a price that is less than the fair market value of the oil or gas, the Manager shall, by notice in writing addressed to the lessee, specify the dollar value of the oil or gas that would be realized if it were sold in a business-like manner, at the time and place of production in an arm's length transaction; and the lessee shall, in his royalty payment next following the receipt by him of the notice, account for and pay to the Manager the deficiency between 
the dollar value specified in the notice and the actual dollar value obtained by the lessee on the sale of the oil or gas. ${ }^{33}$

The current provision is found in s. 33(6) and is not materially different.

A few comments are in order. First, neither of these deeming provisions offers much in the way of procedural protection to the lessee. In each case, the lessee simply receives notice or a direction of the amount of the difference between sale price and market value and a direction to pay. The silence of the regulations however can hardly be conclusive. The implied rules of natural justice and procedural fairness would surely require that the executive director provide the lessee with notice of his intention to make a determination and to give the lessee the opportunity to respond to that notice, at least in written form. ${ }^{34}$

Secondly, on the face of it, s. 21(7) and the current provision in the 1995 regulations are concerned solely with the sale transaction. There is nothing to suggest that s. 21(7) is concerned with the process of netting back from a downstream sale price to find a wellhead price if that is an appropriate way of proceeding. This is important because it has been argued, as shall be seen, that $s .21(7)$ provides a complete code covering all elements of valuation, including the netback calculation. Thus it has been argued that if the manager wishes to contest the deduction of certain processing charges, it can only be done through the s. $21(7)$ process.

\section{PROCEDURAL MATTERS}

Section 41 of the 1977 regulations ${ }^{35}$ provided that a lessee dissatisfied with a decision of the manager ${ }^{36}$ may seek a review of that decision by the minister. The minister is obliged to "review the matter and advise the applicant in writing of his final decision in the matter." The minister is under no explicit duty to provide reasons for the decision. ${ }^{37}$ A review power in almost identical terms is continued in s. 57 of the 1995 regulations.

Supra note 21 . It is not clear whether this section can be applied retroactively or whether it is restricted to present and prospective royalties. In any event, the executive director has been extremely reluctant to use this power and he did not attempt to invoke it in any of the subject cases. See comments below in section III.A.l.

3s Supra note 21 , now replaced by the 1995 regulations, supra note 15 . The substantive rights of the parties in all three cases discussed are governed by the earlier 1977 regulations. Procedure may be governed by the 1995 regulations, see Shell (T.D.), supra note 2 at 242, and Imperial, supra note 1 at para. 5 . Under the 1995 regulations, administrative authority for the Indian oil and gas regime rests with the Executive Director of Indian Oil and Gas Canada. This position was previously titled the Manager, Indian Oil and Gas Canada, and prior to that, the Manager, Indian Minerals West. The prevailing doctrinal position in administrative law is that, in the absence of a statutory duty to give reasons, there is no duty to provide reasons so long as one can infer some reasonable grounds for the decision. See Re Glendinning Motorways (1975), 59 D.L.R. (3d) 89 (Man. C.A.). Note, however, though Rothstein J.'s decision in Imperial, supra note 1, in which he states (at para. 11) that the minister did not offer substantive reasons for eliminating the marketing fee. 
Neither version of the regulations provides a further right of appeal; consequently, the only possible further relief is by way of judicial review in the ordinary course by the Federal Court, Trial Division. While the minister's decision is described as "final," ${ }^{38}$ there is no privative clause in the regulations or the Act. One can anticipate therefore that the standard of review by a court is likely to be correctness for questions of law and reasonableness with respect to all other matters. ${ }^{39}$

Finally, note that both s. 42 of the 1977 regulations and s. 47 of the 1995 regulations allow the executive director, at any reasonable time, to "examine the records of an operator."

\section{The CASES}

\section{A. IMPERIAL OIL RESOURCES V. CANADA (MINISTER OF INDIAN AFFAIRS AND NORTHERN DEVELOPMENT) ${ }^{40}$}

This case involved "deductions" made by Texaco Canada Resources Ltd. ("TCRL"), the predecessor corporation to Imperial Oil Resources Ltd. ("Imperial"), in the form of a 5 percent marketing fee. TCRL sold gas products from the Bonnie Glen field (part of which underlies Pigeon Lake Indian Reserve No. 138A) to its parent company, Texaco Canada Inc. ("TCl"). Under the terms of an agreement between TCRL and TCI, TCI undertook to market gas products acquired from TCRL and agreed to pay TCRL 95 percent of TCI's sale price. TCRL calculated its royalty obligation to Indian Oil and Gas Canada ("IOGC") on the 95 percent netted-back price for the period in question, from August 1979 to the end of 1985.

In 1994, the executive director formed the opinion that the 5 percent deduction was impermissible and decided to audit the pre-1986 TCRL records. ${ }^{41}$ The minister confirmed the decision to disallow the deduction on an application for review. The minister's written reasons referred to his special (fiduciary) responsibilities to First Nations as a reason for eliminating the deduction. In reaching his decision, the minister treated TCI and TCRL as if they were a single entity. ${ }^{42}$ This allowed him to treat TCI's selling price as TCRL's selling price and therefore, self-evidently, an impermissible deduction. A further reason for the minister's decision relied on the fact that the Alberta Crown did not allow similar fees for its share of production from the Bonnie Glen field, although there was evidence that this was the result of negotiations between Alberta and TCRL.

"IOGC had previously audited the $1986-88$ period and Imperial "submitted corrected royalties" for that period.

1995 regulations, supra note 15 , s. 57.

For recent reviews of the cases in an oil and gas context, see Chevron Canada Resources $v$. Alberta (Minister of Energy), [1998] A.J. No. 661, online: QL (AJ) and Petro Canada v. Canada (Canada-Newfoundland Offshore Petroleum Board) (1995), 127 D.L.R. (4th) 483 (Nfld. S.C. (T.D.)).

This is Rothstein J.'s characterization, supra note 1 at para. 10. 
On its application for judicial review, Imperial argued that the minister had erred in disallowing the marketing fee and also argued that IOGC had no authority to conduct an audit. Rothstein J. of the Federal Court, Trial Division quashed the minister's decision. In effect, Rothstein J. ruled that the minister committed an error of law by treating TCRL and TRI as a single entity. ${ }^{43}$ There was nothing in the Indian Oil and Gas $A c t^{44}$ or the 1977 regulations to permit this and thus the common law rule to the effect that a corporation is a separate and distinct legal entity from its shareholders prevails. There were no clear or compelling reasons to displace the normal rule. ${ }^{45}$ Certainly it was not displaced on the basis of the Crown's fiduciary obligations to First Nations. $^{46}$ This argument similarly failed to move Rothstein J. in construing the scope of the executive director's right to audit. ${ }^{47}$ On that issue Rothstein J. made two points. First, the executive director's right to audit under the regulations did not extend to auditing affiliates. Secondly, the power to inspect the records of an operator under s. 42 of the 1977 regulations did not accord a right to conduct a formal audit. ${ }^{48}$

The only relevant provision of the 1977 regulations that could support a right of the executive director to "audit" Imperial's records has already been referred to. It is the right "to examine" conferred by s. 42 as follows:

42. (1) The Manager may, at any reasonable time,

(b) examine the records of an operator at the operation location and at the office of the operator;

Rothstein J., however, concluded:

A review of the Regulations as a whole indicates an elaborate record keeping scheme including the power in the Executive Director to specify the types of records to be submitted for different purposes. The indication is that the Governor in Council was specific in delegating to the Executive Director the power to require and examine records. This leads me to the view that had the intent been to permit an audit, this would have been expressly stated. I cannot subscribe to the view that "examine" includes

Ibid. at paras. 18-22.

S.C. $1974-75-76$, c. 15 .

Supra note 1 at paras. 18-21. Rothstein J. also notes at paragraph 25 that the minister was not without a remedy since under $\mathrm{s.21(7)}$ of the regulations he had the authority to deem a price when of the opinion that a sale occurs at less than market value. This section, notes Rothstein J., was perhaps not invoked either because IOGC was out of time or on the basis that the price received did in fact represent fair market value (at para. 26). There was some evidence to support this in the form of transactions by other parties structured along similar lines.

Ibid. at para. 24.

Ibid. at para. 34. It is not clear why IOGC wished to audit Imperial Oil further when it had already been advised that the 5 percent marketing fee had been deducted in calculating royalties during the period in question.

Ibid. at paras 31-36. The fact that IOGC served notice of intent to audit almost ten years after the date of the records to be audited, may also have influenced the court's decision. The formal order of the court is in fairly broad terms and is set out in Imperial Oil Resources v. Canada (Minister of Indian Affairs and Northern Development), [1998] F.C.J. No. 1708 (C.A.), online: QL (FCJ) (application of the Samson Cree to intervene on the appeal). 
"audit". Clearly, audit is a more formal procedure which, as applicant's counsel points out, places specific obligations on both an operator and the Executive Director that do not appear in the Regulations. ${ }^{49}$

As a result of this decision, it is clear that the audit powers of the department are severely limited, and it is also clear that the minister cannot disallow the deduction of a marketing fee where the Minister's reasoning depends upon piercing the corporate veil. Rothstein J. did not decide and could not decide that Imperial could reduce its royalty obligation by deducting a marketing fee. Presumably, it is still open to the minister to say that there are other good and sufficient reasons for denying the fee, which reasons do not depend upon piercing the corporate veil. For example, it might be reasoned that, since the contract between TCRL and TCI required TCI to sell products "at competitive market values," 50 the actual sales prices achieved by TCI must be the best evidence of actual price, not just for TCI but also for TCRL as the party obliged to pay royalties. The minister might also be able to reason with some conviction, based upon Stoney, that while allowed processing costs can be deducted, the marketing fee claimed does not amount to a processing cost.

The case is on appeal, and the Federal Court of Appeal has rejected an application from the Samson Cree Nation, one of the beneficiaries of the royalty interest, either to be added as a party appellant or as an intervener. ${ }^{51}$ Isaac C.J. gave two reasons for rejecting the application. First, the Samson Cree were aware of the proceedings at trial and could have applied to be added at that stage. Secondly, the memorandum filed in support by the Samson Cree broadened the scope of matters under review, "will range too far from the issues under review," will be unfair to the parties, and will delay the proceedings. This would not, in Isaac C.J.'s view, cause any prejudice to the Samson Cree, for the First Nation was entitled to look to the Crown "as trustee to protect the interests of the Samson Cree Nation." 52

The following section comments on several aspects of Rothstein J.'s decision and provides a lengthy excursus on the pipeline tariff issue that was considered by the minister but never presented to the court on the application for judicial review. Also, some comments are made on the question of the burden of proof.

One of the most striking things about Rothstein J.'s decision is that it reads more like the decision of an appellate court than a decision on an application for judicial review. At several points Rothstein J: says things like "I have not been shown anything that

Imperial, ibid. at para. 32. Contrast this with the views of Gibson J. in Shell, Part III.B., below. Imperial, ibid. at para. 6. The amount of room the minister has here will depend very much upon the terms of the formal order. The order is reproduced at [1998] F.C.J. No. 1708 (C.A.), online: QL (FCJ). Paragraph 1 of the order quashes the actual decision of the minister but then goes on to make certain declarations, including the declaration that there was no evidence on the record of the improper deduction of a marketing fee.

[1998] F.C.J. No. 1708 (C.A.), online: QL (FCJ).

Ibid. at para. 13. Contrast this result with McIntyre J.'s decision in the Stoney case, supra note 3. McIntyre J. granted the band standing to bring an action against the lessee for improper royalty deductions. 
contradicts this evidence" (at para. 14) or "there is no evidence in the case at bar" (at para. 20), as if Rothstein J. were reviewing the evidence afresh rather than attempting to determine if the minister had made an error of law or jurisdiction. Related to this point is Rothstein J.'s failure to consider the appropriate standard of review. Given the comments above that "correctness" is likely the appropriate standard, at least for general questions of law, the result might still have been the same with respect to the corporate veil issue, but the point might be more arguable with respect to other issues. Take, for example, the question of whether or not the term "examine" as used in s. 42 of the regulations included the power to conduct an audit. On this matter the minister and the executive director must deal with the interpretation of their own statutory powers. They must consider the power to examine within the overall framework of the statute and must interpret the statute in a way that is consistent with the Crown's fiduciary obligations to First Nations.

Take another example. Consider the question of whether or not the minister was entitled to look at the substance of the TCI/TCRL transaction. Did the minister have to accept that this was a sale within the meaning of the regulations, or could he look behind the transaction? In the United States there is some suggestion that the courts may be willing to look beyond the characterization placed upon a transaction by related companies. For example, it is arguable that the transactions between the two related corporations (TCI and TCRL) were not purchase and sale agreements, but rather agreements under which one party sold the other party's production in return for a commission. ${ }^{53}$ The lack of an arm's length relation between TCI and its subsidiary, TCRL, would tend to support such an interpretation. For example, the TCI/TCRL agreement provided that the transfer of title of the particular gas products was to go directly from TCRL to the ultimate buyer. ${ }^{54}$ In addition, certain "whole volume" credits were credited to TCRL, not to TCI, even though TCI was allegedly the seller of the export volumes that gave rise to these credits. ${ }^{55}$ This interpretation apparently was not argued by the minister and the executive director, ${ }^{56}$ but one can see that, if it had been, it could have given rise to nice questions as to the appropriate standard of review. ${ }^{57}$

Related to the last point, Rothstein J. was clearly unimpressed with the argument that his interpretation of the regulations should be coloured by the Crown's fiduciary obligations to First Nations. Rothstein J. dealt with this issue in two different parts of

This characterization has been adopted in one American case where the court had to consider a similar non-arm's length sales arrangement. See Taylor Energy 143 I.B.L.A. 80, G.F.S. (O.C.S.) 208 (1998). The decision emphasizes that a federal OCS lessee has an obligation to bear 100 percent of the cost of developing a market for the gas. Presumably the same argument is available here given the lessee's obligation to sell the Crown's royalty share. See also the decision in Stoney, supra note 3, especially at para. 98.

Clause 4(b) of the TCI/TCRL agreement.

See paragraphs 13(c) and (d) of Imperial's submission to DeSorcy and s. 4(a)(ii) of the contract. Supra note 1 at para. 21 .

Or, to take yet another example, suppose that the minister had simply decided that on a strict interpretation of the regulations, reinforced by the Crown's fiduciary obligations, Imperial could not make any deductions for transportation costs. 
his judgment. First, with respect to the minister's claim that he could treat TCRL and $\mathrm{TCI}$ as one entity, Rothstein J. commented as follows:

In oral argument, counsel for the respondents encourage the Court to interpret the Regulations broadly, especially in view of the undisputed fiduciary obligation of the federal Crown towards the First Nations on whose behalf it collects royalties. However, the existence of a fiduciary obligation between the federal Crown and the First Nations does not give the IOGC, the Minister or the Court the authority to read words into the Regulations, which is what the Respondents effectively request. ${ }^{\text {s8 }}$

Rothstein J. returned to this issue in the context of the audit power where he made three separate points. First, he reiterated his view that the fiduciary duty "is not a basis on which to change the meaning of relatively clear legislation." Secondly, following the majority decision in Mitchell, ${ }^{60}$ it would be unwise to introduce uncertainty into commercial dealings with respect to Indian lands. Thirdly, since the relevant provision occurred in a set of regulations, it would be relatively easy for the governor in council to amend it. The minister's reviewer, Mr. DeSorcy, was considerably more impressed by this argument:

Indeed, it is difficult for the Reviewer to believe that the Legislators would intend that there be no right for IOGC to obtain and review the detailed backup information respecting royalty calculations. This is particularly the case given the special relationship between the Crown and First Nations. ${ }^{61}$

Rothstein J. was also troubled by what he perceived to be an unusual and unfair aspect of the Indian oil and gas regime. The 1977 regulations provided that, if gas is sold at arm's length, the value of the gas for royalty purposes is the "gross proceeds" of the sale free and clear of all deductions other than processing costs. As set out above, an arm's length transaction is one arrived at in the market place between independent, non-affiliated persons with opposing economic interests regarding that contract. $^{62}$ If gas is not sold at arm's length but at a lower price, the 1977 regulations provided a mechanism whereby the lessee must then pay royalties based on the fair market value of the gas. However, if the gross proceeds accruing to the lessee are higher than the fair market value, royalties are based on the higher, gross proceeds. The lessor gets the best of both worlds.

Imperial's own evidence indicated that TCI's sales directly from the plant gate were 5 percent higher than the price used by TCRL to calculate the royalties it paid to IOGC. The gas products sold by TCI to third parties were identical to the gas products purportedly sold by TCRL to TCI and were sometimes sold at the same location. Evidence of the fair market value of TCI's products should logically have been evidence of the fair market value of TCRL's products. Since both TCRL's purported sales to TCI and some of TCl's own sales to third parties were at the processing plant gate, the

Supra note 1 at para. 24.

Ibid. at para. 34 [emphasis added].

Supra note 20.

DeSorcy Report, supra note 12 at 20.

See e.g. U.S. Regs. at 30 C.F.R. 206.101. 
marketing fee could not have been a deduction "downstream" of the processing plant. Or, looked at another way, sales by TCI, after it had purchased the gas products from TCRL, were sometimes free on board the plant gate. Since the price of these sales was 5 percent higher than the price on the sales from TCRL to TCI, these sales themselves are evidence that the latter sales were less than fair value.

Rothstein J. seems to have had difficulty with the proposition contained in the 1977 regulations that royalties could be made to be payable on the price at which the gas was sold or fair market value, whichever was greater. In fact, the claim is not entirely unusual. One well-known freehold lease provides that the lessor's royalty share is paid on the "the greater of the actual price received (including payments from any source whatsoever in respect thereof) or the current market value of such substances or any of them, at the time and place of sale in respect of such substance...." ${ }^{63}$ The lessor is not typically prohibited from benefitting from his lessee's marketing acumen. ${ }^{64}$

Furthermore, if the selling price of the lessor's royalty share is in fact higher than someone's determination of fair market value, then by definition that determination of fair market value may be incorrect and should be raised to the level of the selling price, since the selling price was presumably paid by a willing buyer in an arm's length situation. However, in the Imperial situation at Bonnie Glen, IOGC appeared to take the position that arm's length sales did not necessarily establish the fair market value of the products. ${ }^{65}$

\section{EXCURSUS No. 1: THE TRANSPORTATION TARIFF}

One of the most interesting issues raised by Imperial was never brought before the court. In his original decision, the executive director of IOGC decided not only that it had the right to audit but also that: ${ }^{66}$

Imperial has not demonstrated the actual cost of transporting Bonnie Glen crude oil via the Imperialowned pipeline. In the absence of auditable records to substantiate its claim, Imperial shall recalculate all oil royalties from June 1985 onward without any deduction for oil pipeline transportation.

Imperial sought ministerial review of that decision, and the minister appointed Gerry DeSorcy, former chair of the Energy Resources Conservation Board, to advise him on the appeal. DeSorcy's report covers some twenty-three pages of which only a few deal with the natural gas liquids marketing deduction considered in the previous section. The balance of his report is concerned with the transportation toll issue.

See e.g. PanCanadian standard form petroleum and natural gas lease at clause 5 .

See also C.A. Rae, "Royalty Clauses in Oil and Gas Lease" (1965) 4 Alta. L. Rev. 323 at 327. Rae discusses the situation in which the lessee sells on a long-term contract at the prevailing price only to find that the price of gas increases at the wellhead faster than the escalation clauses of the sales contract. Can the lessee be compelled to pay royalty at the market price prevailing from time to time? Rae notes that the point is not settled in Canadian law. That continues to be the case.

See the reply of IOGC to the minister's reviewer dated 7 June 1996 at para. 44. Exhibit to the affidavit of W. Muscoby, part of the applicant's record, 16 January 1997.

DeSorcy Report, supra note 12 at 6. 
The minister accepted DeSorcy's recommendations (which were favourable to Imperial) on the tolling issue, and, as a result, Imperial did not seek judicial review of this aspect of the matter. However, DeSorcy's discussion of this issue sowed the seeds for Rothstein J.'s comments on the applicability of s. 21(7) of the regulations.

It has already been noted that IOGC conceded the principle that Imperial should be entitled to deduct transportation charges prior to determining its royalty liability. Hence, IOGC conceded that, if the sales price was the posted price in Edmonton, then Imperial should be able to deduct the cost of transporting the oil from Bonnie Glen to Edmonton. However, Imperial should be confined to actual costs. If Imperial were unable upon audit to adduce records to show how this tariff was calculated, then no portion of the tariff should be allowed. Another way of putting the matter is to say that it was IOGC's position that the Edmonton sale price was the relevant sales price on which royalty should be paid unless and until Imperial could demonstrate the validity of the netback calculation. This argument placed the burden firmly on Imperial.

In his review, DeSorcy focused on two issues. First, DeSorcy asked whether the Imperial toll was out of line with the tolls charged on similar pipelines. His answer was no. While recognizing that he lacked all the information and that the limited information available made it impossible to do precise tolling calculations, ${ }^{67}$ he carried out a back of the envelope calculation to determine that the tolls were not unreasonable. That led him to conclude that the manager's decision to disallow the tariff (because it contained too large a profit component) was "punitive and was not appropriate." 68

Secondly, DeSorcy considered whether IOGC was entitled to use the audit process to disallow transportation costs or whether it was compelled to use the s. 21(7) process. DeSorcy took the view that this was exactly the type of issue that s. 21(7) was designed to deal with. He put the point this way:

The Reviewer considers that the Bonnie Glen matter at hand is the kind of situation which was anticipated by Section 21(7). The posted price as referred to in the sales agreements is the actual selling price, the actual selling price is reflective of a tariff on a pipeline owned at least in part, by affiliates of the producer and the Manager is concerned that the tariff may be working to reduce the actual selling price to less than the fair market value. ${ }^{69}$

It is important to distinguish here between two views of Imperial's case. On the one hand, and for part of the period under review (1979 to 1992), Imperial took the view that Bonnie Glen oil was sold at Imperial's posted field price. This was contested by IOGC on the basis that "until Imperial filed its submission to the Reviewer, it had never claimed that the actual selling price was the Bonnie Glen posted field price."70 The other view of the case was that the first real market transaction was the posted 
price in Edmonton. Imperial conceded that this was the case for the period post-1992, but also claimed the right to netback from this price to the field.

This distinction is important because it is surely relevant to the question of whether or not s. 21(7) is available. If Imperial's claim is correct and the royalty was calculated by reference to a posted price at the field, then it must follow that the only way to attack that price is through the s. 21(7) process. On the other hand, if the point of sale is Edmonton, then that is the sale price of the product and the price on which Imperial must pay a royalty except to the extent that it can show: (1) that it is permissible to deduct at all for transportation charges, and (2) that these particular charges are an essential part of an arithmetic method for netting back that price to the field (i.e. the time and place of production).

The reviewer made little of this distinction for he accepted that pre-1992 the posted field price was the actual selling price, while after 1992 it was the Edmonton price less the tariff, a price that the reviewer referred to as the "effective field price."71

As stated above, it is unfortunate that these issues were not considered by the reviewing court, but the court did comment on s. 21(7) primarily in the context of the marketing fee issue. Rothstein J. relied on S. 21(7) to meet IOGC's argument that there must be an implied right to treat parent and subsidiary as the same entity so as not to leave a loophole through which royalty obligations could be inappropriately reduced by non-arm's length dealings:

If the Executive Director was of the view that the deduction of the five percent marketing fee from the downstream selling price reduced the selling price at plant gate to less than fair market value, his remedy was under subsection $21(7)$.

For some reason not explained in the material and by counsel, the Executive Director and the Minister did not opt for his solution. [Rothstein J. went on to speculate that perhaps the time delay made it impossible for the Minister to fix a price and concluded as follows:] Whatever the reason, the Executive Director and the Minister have deliberately avoided invoking the obvious remedial provision available to them to deal with non arm's-length transactions and instead have opted for an approach that is not authorized by the Regulations. ${ }^{72}$

Although Rothstein J. took the view that the executive director should have used his s. 21(7) powers, it is not clear whether this can be done on other than a current basis. In other words, it is quite possible that the 1977 regulations did not allow the executive director to redetermine royalty values on an ex post facto basis. ${ }^{73}$ 
The irony here is that DeSorcy did not apply the logic of his s. 21(7) analysis to the marketing fee. Instead, it was his conclusion that whatever the practice in the industry, this was simply not something that was allowed by the regulations. ${ }^{74}$

Although Rothstein J. does not directly address the validity of Imperial's transportation deductions, he did draw attention to the issue indirectly. The point emerges as part of his critique of IOGC. Rothstein J. noted that the executive director had attempted to disallow one type of deduction, namely marketing fees, while allowing or "netting back" other deductions downstream from the wellhead, namely transportation costs. Rothstein J. pointed out that, if the executive director had consistently interpreted the 1977 regulations, he should also have disallowed these transportation deductions:

The purported basis for disallowing the marketing fee charge is that it is not a cost of processing which is the only type of cost that may be deducted under subsection 2(4) of Schedule I of the Regulations. However, the respondents do not take the same position with respect to transportation charges or taxes incurred beyond the plant gate. In essence, the respondents for marketing fee purposes, treat TCRL and $\mathrm{TCl}$ as one entity, but treat them as separate entities for other charges. If indeed the respondents had the authority under the Regulations to pierce the corporate veil and did so, they would be obliged to disallow all non-processing costs. They do not have the power to allow or disallow costs in their discretion. ${ }^{25}$

This passage is interesting for a couple of reasons. First, it offers indirect support for the proposition that a lessee under the 1977 regulations cannot deduct transportation costs at all. Secondly, and to the extent that one accepts the legitimacy of the netback methodology, it seems to suggest that apart from processing costs, all other possible cost deductions stand on the same footing. With respect, this characterization is in error, for if transportation costs can lawfully be claimed by a lessee it must be on the basis that they form an essential part of computing value at "the time and place of production" as part of a netback formula. Thus, given the assumption that this is a legitimate approach, transportation fees stand on a different footing from marketing fees, especially when one of the obligations that the lessee undertakes is the duty to sell the royalty share of gas. There is nothing that obliges the executive director to treat all deductions in the same way. Some deductions may be a legitimate part of determining value at "the time and place of production," while other deductions are not. If a deduction cannot be justified as a legitimate part of the netback process, it can only be deducted if the manager decides that it is a fair and reasonable processing charge for gas. Beyond that, the manager has no discretion to permit further deductions.

As discussed above in section II.B., the 1995 regulations now provide for a much more objective and expanded set of tests for allowable deductions:

74 DeSorcy Report, supra note 12 at 21.

7s Supra note 1 at para. 22. Rothstein J. however, seemed to think that the deductibility of these costs had something to do with whether the costs were deducted by the royalty payor or a third party. Respectfully, he was mistaken in this regard. See McIntyre J.'s comments in Stoney, supra note 3 at para. 98. 
Where gas ... is sold, the royalty payable is the gross royalty value of the gas ... less the portion of the cost of gathering, dehydrating, compressing and processing the gas that is equal to its gross royalty value divided by its total value. ${ }^{76}$

\section{EXCURSUS No. 2: THE BURdEN OF ProOF}

As noted above, DeSorcy glossed over the question of who has the burden of proof with respect to the separate matters of market price and permissible deductions. In fact, the point is a difficult one on which there is little Canadian authority even with respect to freehold leases. Writing in 1965, Cliff Rae argued that, in general, a lessor wishing to challenge a lessee's royalty calculations would have the burden of showing that the lessee was using a non-market price. ${ }^{77}$ The position of the lessor might be different in the case of an in-kind royalty or in a case in which the lessee was selling the lessor's royalty share as agent for the lessor (which may well be the position of the lessee on First Nation lands).

But in any event, the issue of permissible deductions may raise different considerations. A lessee nets back to the wellhead when there is no market at the wellhead. If the lessee wishes to claim that the market price that it received should be reduced by certain costs and charges, then arguably, the lessee should have the two-fold burden of proving as a matter of law that the class of costs is a legitimate deduction and that the specific costs claimed are essential to determining market value at the wellhead.

Hart J.'s judgment in Acanthus $^{78}$ offers some support for this proposition. In that case Hart J. held that a lessee wishing to deduct treatment costs with respect to oil production had the burden of proving, on a balance of probabilities, "the quantum of costs which are actually incurred in gathering, treating and storing the oil produced on the leases before it is delivered to market." ${ }^{79}$ Hart J. offered the following guidance as to the type of evidence that a lessee might adduce:

At a minimum the court would have expected cogent evidence on the specific facilities used for gathering, treating and storage; their original capital cost and their current depreciated value. In addition actual operating costs should have been provided. ${ }^{80}$

While the lessee in that case was able to meet the burden on the first branch of the test and establish an entitlement to deduct treating costs, its evidence fell short of what Hart J. expected on the second branch of the test (i.e., can the lessee deduct for these particular costs?). As a result, Hart J. awarded the lessee one-eighth of the costs that it had sought. 
Hart J.'s decision on burden is not, however, conclusive. On one reading of the case, the lessee had the burden simply because it was the plaintiff. On another reading, the lessee had the burden because it was the party seeking to deduct costs from the market price received for the goods. On this view, the deductions are presumptively zero unless the lessee can establish their amount.

What ought to be the position under the 1977 regulations? If the lessee wishes to rely upon the netback methodology, it must first demonstrate that the regulations allow for this and must also show that the costs claimed are a necessary part of the netback calculation. Beyond that, the lessee must have the burden of showing that its costs fall within processing costs that have been allowed by the manager as fair and reasonable.

\section{B. Shell Canada v. Canada (A.G.)}

In 1982, in order to provide industry with some guidance on permissible gas processing deductions under the 1977 regulations, Indian Minerals West, the predecessor to IOGC, promulgated "Guidelines for the Calculation and Reporting of Gas Cost Allowance for Natural Gas and Associated By-Products on Indian Land." The guidelines explicitly stated that they had no legislative sanction and were not binding upon the government or Indian Minerals West. Shell ${ }^{81}$ deals with the issue of gas processing deductions for royalty gas or Gas Cost Allowance ("GCA").

Shell Canada Ltd. ("Shell") had been producing gas from the Jumping Pound field, a portion of which underlies the Stoney Indian Reserve. Between 1983 and 1988 and pursuant to the guidelines for calculating gas cost allowance, Shell included the capital costs of its relevant capital assets in determining the scope of its royalty obligations and the gas processing fees deducted in determining these obligations. Shell did not deduct the value of investment tax credits ("ITCs") earned by it under the Income Tax $A c t^{82}$ when it included its capital costs in the GCA formula. The guidelines were silent on this question, and it was not until 1991 that IOGC informed industry that it would require Indian lessees to deduct ITCs in calculating capital costs for GCA purposes. In 1995, the executive director decided to claim additional royalty from Shell for the period from 1983 to 1988 on the basis that ITCs should have been deducted from the capital costs included in the GCA formula. Shell appealed that decision to the minister who confirmed the executive director's decision. Shell was successful on its judicial review application and the trial decision has recently been confirmed by the Federal Court of Appeal. ${ }^{83}$

The Federal Court of Appeal gave two reasons for confirming the trial decision. First, the court held that the executive director and the minister had no authority to apply the regulations retrospectively, yet this was what they had both done:

\footnotetext{
8 Shell, supra note 2.

82 R.S.C. 1985 (5th Supp.), c. 1.

83 Shell, supra note 2.
} 
A statute is said to be retrospective not only when it takes away or impairs a vested right, but also when it creates a new obligation, imposes a new duty or attaches a new disability with regard to events already past.

From 1983 - 1988, Shell's royalty returns were filed according to the known guidelines. By adding a new component to those suggested by the guidelines for the purposes of computing GCA, the Manager imposed a new liability on Shell which neither the Act nor the Regulations contemplated. ${ }^{84}$

In coming to this conclusion, the court presumably must also have decided that the former guidelines could not reasonably have been interpreted as requiring the deduction of ITCs from capital costs. ${ }^{85}$ On this interpretation, when the more specific guidelines were announced in 1991, they had the effect of changing the previous guidelines in a retrospective manner.

Although the Act required lessees to pay royalty in accordance with the regulations "as amended from time to time," and although the schedule to the 1977 regulations allowed deductions for such processing costs as the executive director "from time to time" considered reasonable, the court held that both provisions should be interpreted to be prospective in nature. ${ }^{86}$

In making their decisions, both the executive director and the minister had before them a report recommending that ITCs be deducted in calculating capital costs for GCA purposes. Shell was not provided with a copy of that report, and neither was it informed as to the contents of the executive director's submission to the minister during the review by the latter. The court ruled that this was a major procedural error and would have quashed the decision on this ground as well. ${ }^{87}$

The Federal Court of Appeal did not have to deal with a couple of other arguments that had been addressed to Gibson J. on the initial application. There, Shell had contended that to the extent that the minister took into account the Crown's fiduciary obligations to First Nations, it was taking account of an irrelevant consideration. Gibson J. rejected that contention in a couple of passages that are considerably more nuanced than the judgment of Rothstein J. in the Imperial case:

If the IOGC's fiduciary duty was the sole basis on which the Manager here chose "to change the meaning of relatively clear legislation", I would conclude that the decision of the Manager that underlies the decision of the Minister here under review, and therefore the decision of the Minister itself, would be suspect at the very least. But that is not the case here. IOGC's fiduciary obligation was

85 The court's decision turns very much upon the idea that the executive director was making a new decision with retrospective effect rather than simply asserting that this was the proper interpretation of the original guidelines. The point is of dual significance since the executive director is presumably entitled to some deference as to the proper interpretation of the guidelines. The executive director did have advice from Peat Marwick that Shell's treatment of ITCs was not in accordance with the guidelines: see Shell (F.C.A.), supra note 2 at para. 8. 
only one of a number of different considerations taken into account. I conclude it was an appropriate consideration. The obligations of the lOGC, the Manager and the Minister in relation to First Nations in circumstances such as those before me are obligations that should never be lost sight of. That being said, it is an appropriate concomitant of that obligation that it be borne in mind in determining what are fair and reasonable costs of processing. I can only assume that the applicant, a major corporation with extensive experience and sophisticated staff, was conscious of the implications of entering into the leases in question where the lessor had such a fiduciary obligation. ${ }^{88}$

By the same token, Gibson J. also concluded that neither the Crown's fiduciary obligations nor its use of an accounting firm that had also done work for the Stoneys, could amount to an unlawful fettering of discretion. ${ }^{89}$ Both conclusions seem consistent with other authority that asserts that liberal rules of construction applicable to statutes affecting Indians are no less applicable when the litigation involves third parties. $^{90}$

As was the case in the Imperial decision, neither the trial court nor the court of appeal was much concerned with the applicable standard of review. Indeed, subject to the discussion in the following paragraphs, it seems simply to have been assumed that the standard was that of correctness. Thus, for Desjardins J.A. the "issue is whether the Minister was correct" in confirming the manager's decision to require Shell to deduct ITCs to reduce the cost of the relevant capital assets. ${ }^{91}$

It helps to be as precise as possible as to just what it was that the court decided in Shell. Reading the judgments of the two courts together, it is apparent that the court in Shell was of the view that the manager shall allow lessees to deduct processing costs, but only such costs as he considers fair and reasonable. ${ }^{92}$ The court acknowledged that this was a broad discretion ${ }^{93}$ but not an unlimited one. Furthermore, notwithstanding the court's failure to consider the standard of review, the court does implicitly acknowledge that it is the manager in the first instance and subsequently the minister who must determine what is a fair and reasonable cost of processing. ${ }^{94}$ It is not up to the court to substitute its judgment for that of the manager and minister. The corollary of that proposition is that the court did not decide that IOGC cannot instruct its lessees to deduct ITCs from its capital cost claims on a prospective basis.

The issue of what is a "fair and reasonable" cost of processing is a matter of discretion with which the court should not interfere unless the result was patently unreasonable or at least unreasonable. The latter seems to have been Gibson J.'s view.

90 Supra note 20. See Stoney Creek Indian Band v. British Columbia (A.G.), [1998] B.C.J. No. 2468 (B.C.S.C.), online: QL (BCJ) at para. 57 [hereinafter Stoney Creek Indian Band].

II Shell, supra note 2 at para. 2.

$92 \quad$ Jbid. at para. 14, Desjardins J.A. 
In response to Shell's argument that the minister misconstrued the meaning of "cost" in exercising his discretion, Gibson J. said as follows:

In effect, the Manager determined that costs of processing do not include ITCs, or, put another way, ITCs reduce costs of processing. I conclude that this interpretation was reasonably open to the Manager, given the breadth of his discretion. Further, the interpretation did not involve a defining of "costs" of processing in a manner inconsistent with case law. ${ }^{95}$

What the court has decided, is that, as a matter of law, IOGC cannot exercise the power to determine what is a just and reasonable cost of processing on a retrospective basis. Thus, once IOGC has decided ${ }^{96}$ to accept royalties calculated in a particular way by allowing the deduction of certain processing costs, it cannot turn round and change its mind. There is nothing particularly remarkable about this decision, and the courts have recently used several different techniques to limit the capacity of administrative decision-makers to change policy or interpretations retrospectively. ${ }^{97}$

Finally, although the court was not directly concerned with the issue of burden of proof, Desjardins J.A.'s concluding remarks do contain her acknowledgment that the result of according the manager the discretion to determine what are reasonable costs of processing is to throw the burden on to the lessee to establish an abuse of this discretionary power whenever the manager disallows or refuses to allow a claimed processing cost. ${ }^{98}$ Notwithstanding the fact that Rothstein J.'s reasons for decision were made available to counsel before Gibson J. gave his judgment, at no point does either level of court suggest that IOGC can only proceed to question processing costs through the mechanism offered by $\mathrm{s}$. $21(7)$ of the then regulations.

\section{Stoney Tribal Council v. PanCanadian Petroleum 99}

In this case, the claim to additional royalties was commenced by the First Nation itself, not by IOGC. ${ }^{100}$ The issue centred on deductions taken in calculating Indian royalties, but this time the argument of the lessees was that they were entitled to or required to make these deductions as a result of provincial law.

Shell, supra note 2 at para. 38.

This does, of course, beg the question of when the decision was made. To say that it was made when the guidelines were issued involves the assumption that the issuance of non-binding guidelines constitutes a decision and also the assumption that there was only one possible interpretation of the guidelines.

See Alberta (Energy Resources Conservation Board) v. Sarg Oils, [1998] A.J. No. 1039 (Q.B.), online: QL (AJ), Chevron Canada Resources v. Alberta (Minister of Energy), [1998] A.J. No. 661 (Q.B.), online: QL (AJ), Aurchem Exploration v. Canada, [1992] F.C.J. No. 427 (T.D.), online: QL (FCJ).

Shell, supra note 2 at para. 20. "Shell had the burden of proving [on the review of the Manager's decision before the minister] that such a decision, which was supported by IOGC, was erroneous at law."

Supra note 3.

It is not known why the executive director did not pursue the issue himself. 
Provincial laws of general application apply on Indian reserves. But what if those provincial laws affect that which is core to the federal head of power in s. 91(24) of the Constitution Act, 1867? ${ }^{101}$ What constitutes part of the core of s. 91(24)? Is a provincial law that affects the royalty otherwise payable to a First Nation applicable on reserve? These were some of the questions that McIntyre J. of the Alberta Court of Queen's Bench had to consider.

\section{THE FACTS}

The Stoney Nation surrendered certain mineral rights on its Treaty 7 reserves west of Calgary to the federal Crown in trust for the purpose of leasing for the benefit of the band. PanCanadian Petroleum Ltd. ("PanCanadian") acquired interests in two leases by assignment. Lease A was granted in 1973 and renewed in 1982; Lease B was granted in 1975 and renewed in 1985. The leases were granted under the Indian Oil and Gas Regulations passed pursuant to the Indian $A c t^{102}$ and renewed under the terms of the 1977 regulations passed under the Indian Oil and Gas Act. ${ }^{103}$

The Stoneys claimed that PanCanadian had underpaid its royalty obligations by making two types of deductions: first, a deduction for TOPGAS financing charges that were chargeable to and paid by PanCanadian, and secondly, operating, marketing, and administration charges ("OMAC") that were paid by PanCanadian to TransCanada PipeLines Ltd. ("TCPL") to whom PanCanadian sold the gas produced from the reserve.

The original leases both provided that the royalty was to be payable "free and clear of all rates and taxes and assessments and from all manner of deductions whatsoever." The lease renewals both provided that the lessee was to pay the lessor the royalty from time to time prescribed by the regulations. As noted above, ${ }^{104}$ the regulations post-1974 provided that a lessee must pay a basic and a supplementary royalty with "all quantities to be calculated at the time and place of production free and clear of any deduction whatsoever" except as provided under s. (4). Subsection (4), as has been seen, is confined to such fair and reasonable processing costs as are allowed by the manager. As McIntyre J. noted, "The Manager did not allow costs relating to TOPGAS or OMAC, which costs are not, in any event costs of processing." ${ }^{05}$ PanCanadian therefore had to rest its defence on some other, more substantial ground.

The heart of PanCanadian's case was that TOPGAS and OMAC were not processing charges or other deductions but were simply necessary components for determining the "actual selling price" 106 at the time and place of production. In other words, the claim must be that they are an essential part of the netting back process to arrive at a

\footnotetext{
101 (U.K.), 30 \& 31 Vict., c. 3, reprinted in R.S.C. 1985, App. II, No. 5.

102 Supra note 16.

103 Supra note 14.

104 See section II.B.2 above, and the discussion on valuation and the regulations.

105 Supra note 3 at para. 15.

$106 \quad$ Ibid. at para 86.
} 
wellhead valuation, or alternatively, that these charges were simply properly included in "the actual selling price" of the gas. ${ }^{107}$

In order to examine these claims, some background about the origins of the two types of charges is required.

\section{a. The TOPGAS Charges}

In common with many other producers at the relevant time, PanCanadian sold its gas to TCPL under a long-term contract. At the time, TCPL served as a purchaser, aggregator, shipper, and seller of gas, and its contracts included "take-or-pay" clauses that required TCPL to take certain minimum volumes, or to pay even if it did not take. In the event that TCPL was forced to pay, it was entitled to recover the paid-for gas at a later time. While the take-or-pay clauses seemed prudent at the time, the move to regulated prices in the period from 1975 to 1986 depressed demand for gas, and TCPL found itself burdened with massive take-or-pay payments. ${ }^{108}$ TCPL borrowed money to make those payments.

For unknown reasons, TCPL apparently treated the PanCanadian contract as a 100 percent take contract and in fact always called for the maximum daily quantity from the leases in question. ${ }^{109}$ Thus, PanCanadian received no take-or-pay pre-payments from TCPL for production from these leases, although it did receive pre-payments attributable to other production. ${ }^{110}$ The Stoneys no doubt benefitted from this but, equally clearly, PanCanadian had no contingent liability to deliver prepaid gas to TCPL under these leases, for there was no such liability.

The litigation covers the period from 1982 to 1995 . During the first part of that period, gas prices were regulated and then subsequently de-regulated. During the period of regulated prices, price was based on a netback formula starting with either a regulated "Toronto City Gate" price or a regulated "Alberta border" price and then deducting back the cost of service to arrive at a regulated field price. This occurred pursuant to federal-provincial agreements supported by federal "' and provincial statutes. In Alberta, the Alberta cost of service component ("ACOS") was determined by the Alberta Petroleum and Marketing Commission ("APMC") under the terms of the Natural Gas Pricing Agreement Act. ${ }^{12}$ Separately, the Alberta Department of Energy

Jbid. at para. 98.

For a similar scenario, see Petrogas Processing v. Westcoast Transmission, [1989] 4 W.W.R. 272, aff'g [1988] 4 W.W.R. 699 (Q.B.).

Supra note 3 at paras. 29,41 , and 103. As a result, TCPL apparently took more than 100 percent of the contracted volumes. The consideration for this arrangement flowing to and from PanCanadian, if any, is also unknown.

Ibid. at para. 41.

Petroleum Administration Act, S.C. 1974-75, c. 47.

S.A. 1975 , c. 38. 
permitted the deduction of the ACOS in calculating Alberta Crown royalty obligations. ${ }^{113}$ The APMC allowed TCPL to include its financing charges for its take-or-pay payments in the ACOS:

It decided that this was appropriate because it considered the financing charges to be a cost attributable to the acquisition of gas. TCPL had been prudent in incurring the obligations. The charge applied to all producers, not just those who had benefitted from take-or-pay payments. All producers had to share the costs because it was an industry-wide problem. In other words, interest charges on TCPL's borrowing costs were part of the ACOS. The ACOS was netted back in calculating the Regulated field Price, upon which royalty calculations were based. Thus the royalties were calculated on an after take-or-pay financing charges basis. ${ }^{114}$

As the problem compounded for TCPL, TCPL and its producers entered into the "TOPGAS Agreement." Under the terms of that agreement, TCPL created a holding company, TGH, to which it transferred some of its rights and obligations for take-or-pay gas. TGH paid $\$ 2.3$ billion to the producers in prepayments and the producers in turn paid TCPL $\$ 1$ billion to erase their liability for prepaid gas. The producers kept the balance of $\$ 1.3$ billion but, in turn, owed $\$ 1.3$ billion in prepaid gas. ${ }^{115}$ The plan was for them to pay this off over time with gas and cash. A second iteration of the agreement, TG2, expanded the scope of the original plan. As a result of these arrangements, the producers had effectively assumed significant financing charges. The APMC allowed these costs as well to be included within the ACOS and, in a series of decisions, apportioned a greater share of these costs to those contracts that bore greater responsibility for the take-or-pay problem. ${ }^{116}$ On that basis, the PanCanadian-TCPL contract that included Stoney gas was placed in "Category A" by TCPL and PanCanadian, which category bore the highest allocation of TOPGAS financing charges. TCPL effectively collected these financing charges for TGH and TG2.

With the deregulation of gas prices and the unbundling of TCPL's functions, it was necessary to provide a firm legislative basis to continue this scheme, and accordingly, the Alberta legislature passed the Take-or-Pay Costs Sharing Act ${ }^{117}$ following a recommendation of the National Energy Board (the "Board")."18 The Board characterized the TOPGAS charges as being related more to gas acquisition than to

See Information letter 87-5, Natural Gas Royalty Administration Principles Resulting from Deregulation, especially para. 3, Cost Deductions and especially Subpara. (b), Taxes, Levies and Other Charges which may be Levied by Governments: "taxes, levies and other charges which may be levied by governments on minerals, including natural gas products, are not allowable as deductions. One exception to this is the take-or-pay levy under the Take-or-pay Costs Sharing Act, which the minister may authorize to be deducted pursuant to s. 11.1 of the Natural Gas Royalty Regulations."

114 Supra note 3 at para. 34 .

115 Ibid. at para. 38.

$116 \quad$ lbid. at para. 40.

117 S.A. 1986, C. T-0.1.

118 RH-5-85. 
transportation. This provincial statute "essentially legislated the collection of TOPGAS financing charges." 19 The PanCanadian-TCPL contract remained in Category A.

Neither IOGC nor the Stoneys consented to it being so allocated, and there was no evidence to indicate that at any time did IOGC or the Stoneys participate in or consent to any of the above arrangements. The 1977 regulations were not amended to accommodate the APMC's practice of including these charges as part of ACOS. ${ }^{120}$ Finally, although the APMC did divide gas into certain categories as described above, at no time did the APMC or the legislation instruct a producer how to allocate those costs. $^{121}$

\section{b. OMAC}

The picture for OMAC is far less complicated. Upon deregulation of prices in 1986, TCPL had to negotiate a purchase price with its producers. TCPL did this by entering into an agreement with its producers, the "Netback Pricing Agreement," pursuant to which all gas sold by TCPL was pooled. OMAC and various other amounts were then deducted with the balance remaining divided by the total amount of gas sold, thereby yielding the netback price. Under a later netback pricing agreement, OMAC took the form of an amount incurred by Western Gas Marketing for operating, marketing, and administrative services. Western Gas Marketing was the gas marketing subsidiary of TCPL. ${ }^{122}$

Of the two issues, OMAC and TOPGAS, it was the latter that was much the more significant in financial terms. The central question for McIntyre J., therefore, was whether the scheme for collecting TOPGAS charges, whether incurred by TCPL or the producers, was a mechanism for determining price, or whether it was a deduction from price, and, in any event, whether this mechanism, which was authorized under provincial law, was opposable against Indian royalties.

\section{THE LAW}

\section{a. Section 88 of the Indian Act}

McIntyre J. began with the latter part of the question and broke it down into two components. First, assuming that the provincial law was applicable to Indian royalty

Ibid. at para. 80. "It does not purport to decide how that fee is to be apportioned among various parties." See also Petro Canada Oil and Gas v. Consolidated Gathering Systems (unreported memorandum of judgment of Rooke J. [hereinafter Petro Canada], aff'd by the Court of Appeal, 7 December 1995 and Digest 394, Canadian Oil and Gas. The case is authority for the proposition that the role of the APMC is limited to determining equities as between TCPL and its producers and not as between a purchaser and seller of gas. 
gas, did s. 88 of the Indian Act prevent it from applying? ${ }^{123}$ Secondly, even if s. 88 prevented the law from applying through referential incorporation, could it apply of its own force or was it prevented from doing so, since, insofar as it purported to apply to Indian royalty gas, it trenched upon a core area of the "lands reserved" head of federal jurisdiction? As part of this second question, McIntyre J. needed to know whether the Stoney royalty interest was an interest in land and therefore part of the lands that were reserved to Indians under s. 91(24) of the Constitution Act, 1867. ${ }^{124}$ That question was also relevant to the limitations issues raised in the case.

Section 88 of the Indian Act makes provincial laws of general application apply to Indians even if those laws would not apply to Indians of their own force because they touch or impair a core federal jurisdiction. ${ }^{125}$ However, the opening and closing phrases of the section also act as a shield. Thus, provincial laws will not apply to Indians if that provincial law: (1) conflicts with the terms of a treaty; (2) conflicts with any other Act of Parliament; (3) conflicts with the Indian Act, or any order regulation or by law made thereunder; or (4) makes provision for any matter for which provision is made under the Indian Act. The last clause is perhaps the most significant for it is generally acknowledged to state a form of the paramountcy doctrine that is broader than the operational conflict doctrine espoused by the Supreme Court of Canada over the last number of decades. ${ }^{126}$

Was there a conflict then between the "free and clear of any deduction whatsoever" language of the regulations and the TOPGAS scheme? Could the Stoneys succeed simply by showing the provincial scheme was making provision for a matter already covered by the Indian Oil and Gas Act? ${ }^{127}$ To a great extent, the answer to that

This assumes, of course, that the provincial legislation, if applicable, did in fact establish the "price at which the gas was sold" for purposes of the 1977 regulations. The Alberta government did not rely solely upon the Take or Pay Cost Sharing Act for the purposes of establishing gas prices for the purpose of calculating Alberta Crown royalties; it separately issued Information Letter IL 87-5 to clarify the situation.

Actually, McIntyre J. effectively began the analysis part of his judgment with this question (supra note 3 at para. 53) once he had decided that the Stoneys (and not just the Crown) had the right to bring the action (at para. 52).

It is not clear that $\mathrm{s} .88$ will save a law that is inapplicable because it impairs the "lands reserved" head of s. 91(24). See discussion infra, notes 126 and 138.

Multiple Access v. McCutcheon, [1982] 2 S.C.R. 161. See B. Ryder, "The Demise and Rise of the Classical Paradigm in Canadian Federalism: Promoting Autonomy for the Provinces and the First Nations" (1991) 36 McGill L.J. 308.

The point is not straightforward. Section 88 of the Indian Act extends the federal paramountcy rule to those matters for which provision is made by "this Act," i.e. the Indian Act. It does include the Indian Oil and Gas Act and regulations under this broad protective umbrella; they may only be protected by the more specific conflict rule contained in the opening words of $s .88$. Alternatively, s. 88 may be interpreted as according the Indian Oil and Gas Act the same status as the Indian Act for this purpose for the following reasons: (1) the Indian Oil and Gas Act has evolved out of the Indian Act (see Appendix A to the judgment); (2) the leases in question were originally granted under the Indian $A c t$; (3) under the present regime there is still a requirement for a surrender under the Indian Act before lands can be leased under the Regulations; and (4) any ambiguity will be resolved in favour of the Indians: Nowegijick v. R., [1983] 1 S.C.R. 29. Perhaps McIntyre J. thought that he did not have to answer this question, for he seems to have found what he described as a "direct conflict" (supra note 3 at paras. 87-88). 
question depends upon how one characterizes the TOPGAS scheme. Is it simply part of price determination, in the same way as true cost-of-service charges form a legitimate part of a netback pricing scheme, as PanCanadian and Alberta contended? Or is it an attempt to force royalty holders to bear certain costs that they would not otherwise bear? Is it an attempt to deem certain industry costs to be part of a net-back pricing mechanism? McIntyre J. preferred the interpretation developed by the Stoneys:

I do not accept [the PanCanadian and Alberta] characterization. The federal regime requires royalties to be calculated based on the price. It sets the price to the extent that it allows no deductions to be made. The provincial regime also attempts to set that price by requiring certain deductions. A party cannot comply with both. Moreover, there is a direct connection between the royalties and the price. It is not tenable to say that price-directed legislation attempts to determine the price upon which the royalties are calculated. Thus there is a conflict between the federal and provincial legislation. ${ }^{128}$

On the facts of the case, Stoney gas benefitted from TCPL's 100 percent take policy on this particular contract. ${ }^{129}$ In the absence of a common law duty to prorate the available market among all producers, the policy decision of the APMC (and subsequently of the provincial legislature) to force a sharing of the down-side risks of TCPL's contracting policies was simply that, a political policy decision. It was not mandated by deep-seated principles of the common law. The provincial government could not directly deem a price for Indian royalty gas (and did not purport to do so for other gas on which royalties were payable) and neither should it be able to do so indirectly. ${ }^{130}$ In Enchant Resources v. Dynex Petroleum, ${ }^{131}$ the court held that the province had the legislative capacity to do this for non-Indian production, but that should come as no surprise. McIntyre J. concluded that Enchant was irrelevant to the issue before him.

This was sufficient to decide the case, but McIntyre J. went on to consider the yet more radical claim that the legislation was inapplicable to Indian lands, absent incorporation by s. 88 .

\section{b. Lands Reserved and the Application of Provincial Laws}

The claim here is that while the TOPGAS legislation is clearly intra vires the province, it is inapplicable to the extent that it touches or impairs the core subject matter of s. 91(24) (in this case, the "lands reserved" head) and is not otherwise saved by referential incorporation via s. 88 of the Indian Act.

The first step in the argument, as noted above, was to determine the proprietary status of the Stoney interest in the royalty. In McIntyre J.'s view, ${ }^{132}$ the Crown's

Supra note 3 at para. 87.

Quaere whether PanCanadian would have proffered royalties to the Stoneys on any take-or-pay prepayments had such been paid to PanCanadian?

Supra note 3 at para. 98.

(1991), 123 A.R. 81 (Q.B.) [hereinafter Enchant]. See also Petro Canada, supra note 121 at 207. Supra note 3 at paras. 53-62. 
reserved royalty interest was an interest in land, either on the basis that a reserved royalty was akin to a rent, on the basis that the Crown's reversionary interest was an interest in land, or on the basis that the lessor's right "is a right held in common with the lessee to participate in the development of the lessor's minerals and ... an interest in land appurtenant to the lessor's reversionary interest." The latter finding is based upon the Alberta Court of Appeal's decision in Scurry-Rainbow Oil v. Kasha. ${ }^{133}$

While the conclusion on this point is, with respect, correct, it would have been preferable to reach that conclusion either on the basis of the language of reservation in the original leases and the rent analogy, or on the basis of the reserved royalty as a sui generis interest in land. The characterization of the lessor's royalty interest as a right held in common with the lessee is a dangerous fiction. The lessor does not hold an undivided interest in the exclusive profit $\dot{a}$ prendre held by the lessee ${ }^{134}$ and has no present right of possession. ${ }^{135}$ It is simply false to say that the lessor has a right "in common" with the lessee.

Not only was the Crown's interest an interest in land, so too was the Stoneys' interest. Their interest was a beneficial interest in the Crown's legal interest in the land. ${ }^{136}$

All of this allowed McIntyre J. to conclude that the Stoney interest in the royalty was a proprietary interest and therefore within the scope of the "lands reserved" head of s. 91(24). Did the provincial legislation in question here affect an integral part of the primary federal jurisdiction? ${ }^{137}$ While McIntyre J. wasted little time contemplating the scope of s. 91(24), he went on to hold that provincial legislation that required a producer to charge TOPGAS financing costs to Indian royalty gas was legislation in relation to Indian land use and hence inapplicable. ${ }^{138}$ It was not saved by $\mathbf{s} .88$ of the Indian $A c t,{ }^{139}$ and it was not saved by s. 4 of the 1977 regulations which required operators to comply, as a term of their leases, with provincial laws "relating to the environment and the exploration for, development, treatment, conservation and equitable production of oil and gas." 140 The Take-or-Pay Costs Sharing Act was not such a law. ${ }^{141}$

134 See St. Lawrence Petroleum v. Bailey Selburn Oil and Gas, [1963] S.C.R. 482, affg 41 W.W.R. 210 (Alta. S.C. (A.D.)), aff'g 36 W.W.R. 167 (Alta. S.C. (A.D.)).

13s The right of possession is the only unity required for a tenancy in common.

136

Supra note 3 at para. 64, following Re Stony Plain Indian Reserve (1981), 35 A.R. 412 at 440 (C.A.) noting that in the case of a lease by the Crown of surrendered lands in perpetuity "[t]he Band still retains its interests as beneficial landlord...." See also Chevron, supra note 5.

The question is posed in Stoney, supra note 3 at para. 89.

Ibid. at para. 94.

McIntyre J. does not specifically address the point. There is, of course, a long-standing dispute as to whether s. 88 is confined to the "Indians" head of s. 91(24). See Stoney Creek Indian Band, supra note 90 concluding that the balance of authority favours the view that $\mathrm{s} .88$ is confined to Indians and does not apply to lands reserved.

Supra note 21 , s. 4(d).

Supra note 3 at para. 97. 


\section{c. Other Defences}

On the basis of the above, PanCanadian was liable to the Stoneys for additional royalties. Were there any defences available to PanCanadian? Other than the partial limitations defence, ${ }^{142}$ McIntyre J. dismissed all of PanCanadian's other arguments. Thus, he held that PanCanadian could not defend: (1) on the basis that TCPL made the deductions and not PanCanadian; ${ }^{143}$ (2) on the basis that the Stoneys benefitted from TCPL's 100 percent take under the TCPL-PanCanadian contract (this did not constitute an unjust enrichment of the Stoneys by PanCanadian); ${ }^{144}$ (3) on the basis that the Stoneys could have taken their royalty in kind; ${ }^{145}$ (4) on the basis that it would be inequitable to allow the Stoneys to recover since PanCanadian was still liable to TCPL (that was PanCanadian's problem); ${ }^{146}$ or (5) on the basis of estoppel (the Stoneys never made any representations to PanCanadian or acquiesced in its deductions). ${ }^{147}$

As to the limitations issue, McIntyre J. held that, since the Stoneys had failed to provide notice of an attack on the constitutional applicability of the provincial Limitation of Actions Act, ${ }^{148}$ they were subject to the terms of that Act. However, while their arguments of breach of trust and fiduciary obligations against PanCanadian had failed on the basis that PanCanadian (as distinct from the Crown) owed no such duty to the Stoneys, ${ }^{149}$ the Stoneys were still entitled to the benefit of a ten-year limitation period on the basis that their action was an action that was a proceeding to recover an interest in land. ${ }^{150}$

Infra at note 149.

Supra note 3 at para. 101. "For purposes of royalty calculations under the IOGR, it is irrelevant which party makes the deductions. Deductions are not permitted." Contrast this finding with Rothstein J.'s findings in Imperial, supra note 1.

Stoney, supra note 3 at para. 103.

Ibid. at paras. 105-106. The 1977 regulations only purport to permit IOGC, and not the First Nation beneficiary, to take the royalty in kind.

Ibid. at para. 108.

Ibid. at para. 111 .

R.S.A. 1980, c. L-15. See the Stoney Creek Indian Band, supra note 90. Similarly, the Stoneys were not challenging the vires of the Limitation of Actions Act, but simply argued that it did not apply. Notice had been provided to the Alberta Crown in regard to the constitutional issue of the Take or Pay Cost Sharing Act.

The issue is discussed in Stoney, supra note 3 at paras. 65-74 and at paras. 117-18. McIntyre J. reached that conclusion having applied the test based upon Wilson J.'s judgment in Frame v. Smith, [1987] 2 S.C.R. 99. An alternative test would be to ask whether it is reasonable for the Stoneys to have formed the conclusion that PanCanadian would reasonably owe a duty of undivided loyalty to the Stoneys. This test seems more consistent with the court's judgment in Hodgkinson v. Simms, [1994] 9 W.W.R. 609 (S.C.C.). Note that this does not dispose of the argument that applicable laws must still be interpreted in light of the Crown's fiduciary obligations. See Gibson J.'s comments in Shell, above. Quaere, however, whether the lessee's duty to market the royalty share under s. 21(3) creates an agency relationship which in turn attracts the fiduciary label: see Guerin v. R. (1984), 13 D.L.R. (4th) 321 (S.C.C.), Estey J. at 347-439.

Supra note 3 at para. 122. The reasoning is thin on this point. A royalty is a non-possessory interest. Is an action for additional royalties so self-evidently a claim to recover land just because a royalty is an interest in land? See Canadian Pacific Railway v. Turta, [1954] S.C.R. 427, especially per Estey J. and Rand J. and Re Panther Resources (1984), 29 Alta. L.R. (2d) 220. 
What conclusions can be drawn from McIntyre J.'s important judgment?

First, it seems important to emphasize that the case was not concerned with processing charges. The Stoneys were able to bring this case in a provincial superior court directly against the producer because it raised a pure question of law. Had it, for example, been their argument that IOGC had cut the producer too much slack in allowing PanCanadian to make unreasonably large deductions for processing costs, the Stoneys would have had to bring a judicial review application in Federal Court with the burden of proving that the manager's exercise of his discretion was unreasonable or patently unreasonable. Alternatively, they might have brought an action for breach of a fiduciary obligation.

Secondly, aside from the constitutional argument, the case stands as authority for the proposition that a First Nation beneficiary will be able to question the charges and deductions claimed by a lessee when the lessee seeks to netback from the "the price at which gas is sold" to the wellhead, or alternatively where the lessee seeks to hide behind a non-IOGC regulator's decision to the effect that certain non-processing costs are legitimately to be taken into account prior to calculating royalty liability. Certainly, if upheld on appeal, the case establishes, at least with respect to a First Nation plaintiff, that s. 21(7) is not the only mechanism for questioning the validity of a lessee's netback calculations, ${ }^{151}$ at least to the extent of questioning whether a particular charge can, as a matter of law, be included in the netting back process. McIntyre J. put the point this way:

PanCanadian says that the "actual selling price" was the Regulated Field Price, the Contract Price and the Specific Contract Price at the relevant times .... That was the amount received by PanCanadian. It was appropriate to calculate the royalty on the amount received. However, the Court must look past the terminology employed by PanCanadian and TCPL to understand the essence of the transaction. In essence, the monies paid by TCPL to PanCanadian were net of obligations owed by PanCanadian, not the Stoneys. These obligations comprised TOPGAS financing charges which PanCanadian was obliged to pay to TGH and TG2, and which were collected by TCPL, and OMAC charges initially payable to TCPL and later to WGML. Each was an obligation of PanCanadian. PanCanadian cannot pay its obligations from monies received from the sale of the Stoney's gas, and then say to the Stoneys the royalty is to be calculated on the net amount received. ${ }^{152}$

Why?

The TOPGAS financing charges and OMAC should not be taken into account when calculating royalties from the Stoney's leased lands. They are deductions from the actual selling price that are not allowed under the Indian Oil and Gas Act, the IOGR or the Leases. ${ }^{153}$ noting that the manager did not avail himself of this procedure. Note that a First Nation has no access to the s. $21(7)$ process. or whether he meant to refer to the price at which the gas was sold, since there was no discussion or evidence of "fair market value." lbid. at para. 99. 
It is difficult to reconcile both the approach and the actual decision here with Rothstein J.'s decision in Imperial.

Thirdly, McIntyre J.'s judgment contains no discussion of the question of burden. The parties seem to have proceeded on the usual basis that the plaintiff had the burden of proving its case that the deductions were impermissible.

Fourthly, it is useful to reflect on what the result might have been if IOGC had taken the initiative in this matter. IOGC would undoubtedly have acted differently. Rather than suing for an amount owing, it would have had to have used s. 21(7) or simply have rejected PanCanadian's netback calculations. In either case it is not clear that IOGC would have been able to have reached back very far. As has been seen, the Shell decision stands for the proposition that once IOGC had accepted certain deductions, it could not go back and re-calculate royalty obligations net of those obligations but could only do so prospectively. Given Shell, one assumes that the courts might well also prefer a prospective interpretation of s. 21(7). Thus, although Shell accepts that the result of IOGC disallowing a deduction is to impose the burden on the lessee to justify those charges, the limitations advantages of the First Nation taking the action seem clear. ${ }^{154}$ The First Nation will not be met by the administrative law equivalent of an estoppel argument, or, more precisely, the defendant lessee will find it very difficult to make out the requisite elements of estoppel. ${ }^{\text {iss }}$

Fifthly, it is important to emphasize that McIntyre J. offers two very different types of reasons for disallowing the charges. The first reason is simply that the regulations prohibit any deductions except allowed processing charges. The charges in question did not fall into that category, and neither charge was an essential or integral part of determining a netback price. The fact that the lessee has to make a payment to a third party in respect of gas produced on Indian lands does not in and of itself make that payment an essential element of the netback. The second reason is the constitutional aspect. While it is entirely lawful for the provincial legislature to make the disputed charges an essential part of the netback formula for the purposes of determining a working interest owners' royalty liability, the province cannot do so for the purposes of an Indian royalty liability. It may make a lessee pay particular costs but it cannot authorize the lessee to pass those costs on to the Indian royalty holder.

Sixthly, insofar as McIntyre J. bases his judgment on the proposition that neither TOPGAS or OMAC should be deductible simply because neither qualify as processing charges, then the case also lends some limited support for the proposition that transportation charges are also not a legitimate deduction. That said, it must be emphasized that the only element of ACOS put at issue was that of the TOPGAS financing charges.

The decision is under appeal. making. The First Nation will, of course, have to bear the burden of running the litigation. 


\section{CONCLUSIONS}

Not all costs are processing costs. - The 1977 Regulations distinguished between processing costs for gas and all other costs. The regulations allowed a lessee to deduct processing costs to the extent that the manager considered those costs to be fair and reasonable. The Shell case established that the manager's decision must be made on a prospective basis. The manager's power is discretionary and reviewable on an application for judicial review, presumably by any party with a legitimate interest. Where the manager has disallowed a particular category of costs, the party seeking to deduct those expenses will have the burden of proof. The standard of review will likely be patent unreasonableness. Where an interested party (e.g. a First Nation) seeks to argue on a judicial review application that the manager should not have allowed a particular deduction, it presumably will have the same burden and face the same standard of review. Where a First Nation raises this question collaterally, the Stoney case suggests that the standard is correctness.

"Free and clear of any deduction whatsoever." - The meaning of any royalty obligation is fundamentally a matter of construction. ${ }^{156}$ It is possible for a lessor to force a lessee to bear all the costs of transportation and processing, but, to do so, the drafter must take care to make that stipulation. Arguably, the 1977 regulations sought to achieve this result by adopting the words "free and clear of all deductions," but those regulations also made reference to the time and place of production (i.e. the wellhead), at least for the limited purposes of determining "quantities or amounts." It is an open question whether this language was sufficient to permit lessees to incorporate the netback methodology adopted as industry practice and endorsed by Acanthus. ${ }^{157}$ Certainly, the department seems to have accepted this proposition by its practice, and the proposition has also been incorporated more definitively into the new regulations.

Not all costs should be included in the netback calculations. - But even if the regulations are interpreted to permit the adoption of the netback methodology to move from the first point of sale to arrive at a wellhead price, it does not follow that all of the costs incurred by a producer can be considered as part of this netback arrangement. The Stoney case supports this proposition. The issue is not "are the proposed costs fair and reasonable" but rather, as a matter of law, are they essential to determining a netback price. The Stoneys seemed to accept that they had the burden of proof for this type of claim. Since the matter was commenced as an action and not as an application for judicial review, the question of standard of review did not arise.

The authority to question "fair market value" is not the only basis on which to question the legitimacy of particular deductions. - There is a market price when a willing seller and a willing buyer negotiating at arm's length can agree on a price for the product. The executive director has the power to question whether or not a lessee has sold for a market price. This power is stipulated in both the 1977 and 1995 regulations. There is clearly a body of opinion (DeSorcy and perhaps Rothstein J.) who 
believe that this is the only means by which IOGC can question the netback methodology adopted by a lessee to determine a wellhead value. The authors reject that proposition. Implicitly, the proposition must also have been rejected by the courts in both the Shell and Stoney cases. Both cases proceed on the assumption that the manager has the residual authority to deny a lessee the opportunity to deduct certain costs from its sale price.

Determining market price. - Market price was not raised directly in any of these cases, and IOGC made no attempt to use its deeming power under the regulations. There are hints of larger questions here. For example, DeSorcy alludes to the fact that Imperial did not necessarily accept that Imperial's posted field price was a market price. The issue was not pursued. That issue, the use of the "posted price" system for the purposes of royalty calculations, is currently front and centre with federal oil and gas leases in the United States. The United States Department of the Interior has joined litigation that questions whether the lessees' posted prices are in fact fair market value. $^{158}$ Unless IOGC adopts its own procedures for deeming price based on, for example, AEC-hub prices, IOGC may need to determine whether posted prices, reference prices and other such non-arm's length valuations do in fact produce fair market values. ${ }^{159}$

The fiduciary duty of the Crown. - Rothstein J. played down the significance of the Crown's fiduciary duty to First Nations in developing his interpretive approach to the regulations. Gibson J. took a very different view in the Shell case, and the court of appeal found it unnecessary to comment. The issue arose in a very different context in the Stoney case since the plaintiffs sought to argue that PanCanadian was a trustee for the Stoneys rather than a more limited interpretive argument. It is to be hoped that the Federal Court of Appeal will offer more guidance on this issue when it hears the appeal in Imperial. 66. 


\title{
Recent Judicial Developments of INTEREST TO OIL AND GAS LAWYERS
}

\author{
Nigel BANKes ${ }^{\circ}$ and Alicia Quesnel“"
}

In this article, the authors identify and discuss recent cases that impact on the oil and gas industry. These cases cover different areas of law including constitutional law, lands, leases, and titles, industry agreement, and fiduciary obligations.
Les auteurs identifient et examinent plusieurs arrêts récents déterminants pour le secteur pétrolier et gazier. Ces causes couvrent divers secteurs de droit - droit constitutionnel, biens-fonds, baux et titres, accord relatif $\dot{a}$ l'industrie et obligations fiduciaires.

\section{TABLE OF CONTENTS}

I. Constitutional LaW ................... 296
A. WESTCOAST ENERGY V. CANADA

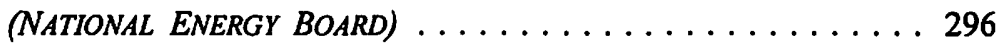
B. CANADIAN HUNTER EXPLORATION V. CANADA
(NATIONAL ENERGY BOARD) . . . . . . . . . . . . 299

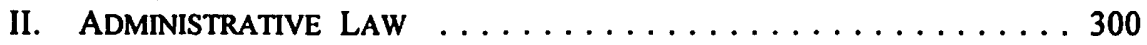
A. ST. JOHN'S (CITY OF) V. CANADA (CANADA- NEWFOUNDLAND OFFSHORE PETROLEUM BOARD) . . . . . 300
B. ALBERTA (ENERGY RESOURCES CONSERVATION BOARD)

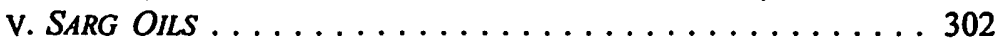
C. KELLY LAKE CREE NATION V. BRTISH COLUMBIA (MINISTRY OF ENERGY AND MINES): THE MOUNT MONTEITH DECISION . . 307
D. CHEVRON CANADA RESOURCES V. ALBERTA (MINISTER OF ENERGY) $\ldots \ldots \ldots \ldots \ldots \ldots \ldots \ldots \ldots$

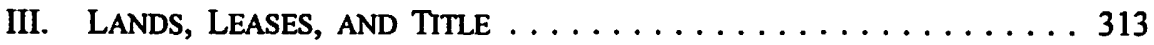

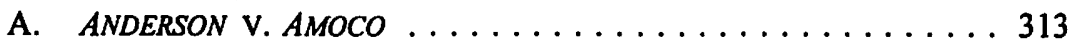

B. TAYLOR V. SCURRY RAINBOW (SASK.) . . . . . . . . . . . 316

C. PADDON HUGHES DEVELOPMENT V. PANCONTINENTAL OIL . . . 320

D. DURISH V. WHITE RESOURCE MANAGEMENT . . . . . . . . . 325

E. ALBERTA (ENERGY RESOURCES CONSERVATION BOARD)

v. SARG OILS . . . . . . . . . . . . . . . . . . . . 330

Professor of Law, Faculty of Law, University of Calgary. This article draws, in part, upon digests prepared by Nigel for Canadian Oil and Gas, the Rocky Mountain Mineral Law Foundation's Mineral Law Newsletter and a paper he prepared for the Canadian Bar Association Mid-Winter Meeting, Edmonton, January 1999. Nigel was responsible for preparing the following parts of this article: Part II - ADMINISTRATIVE LAW; Part III - LANDS, LEASES AND TITLE; Part IV - INDUSTRY AGREEMENTS; Part VIII - ROYALTY CASES. Responsibility for Part VI FIDUCIARY OBLIGATIONS was shared.

-. Associate, Bumet, Duckworth \& Palmer, Calgary, Alberta. Alicia was responsible for preparing the following parts of this article: Part I - CONSTITUTIONAL LAW; Part V - CREDITORS' REMEDIES; Part VII - SURFACE RIGHTS. Responsibility for Part VI — FIDUCIARY OBLIGATIONS was shared. 